\title{
Flipping the Classroom: Old Ideas, New Technologies
}

DOI:

10.1016/j.iree.2018.06.001

\section{Document Version}

Accepted author manuscript

Link to publication record in Manchester Research Explorer

\section{Citation for published version (APA):}

Becker, R., \& Birdi, A. (2018). Flipping the Classroom: Old Ideas, New Technologies. International Review of Economics Education. https://doi.org/10.1016/j.iree.2018.06.001

\section{Published in:}

International Review of Economics Education

\section{Citing this paper}

Please note that where the full-text provided on Manchester Research Explorer is the Author Accepted Manuscript or Proof version this may differ from the final Published version. If citing, it is advised that you check and use the publisher's definitive version.

\section{General rights}

Copyright and moral rights for the publications made accessible in the Research Explorer are retained by the authors and/or other copyright owners and it is a condition of accessing publications that users recognise and abide by the legal requirements associated with these rights.

\section{Takedown policy}

If you believe that this document breaches copyright please refer to the University of Manchester's Takedown Procedures [http://man.ac.uk/04Y6Bo] or contact uml.scholarlycommunications@manchester.ac.uk providing relevant details, so we can investigate your claim.

\section{OPEN ACCESS}




\section{Accepted Manuscript}

Title: Flipping the Classroom: Old Ideas, New Technologies

Authors: Ralf Becker, Alvin Birdi

PII:

DOI:

S1477-3880(18)30045-8

Reference: https://doi.org/10.1016/j.iree.2018.06.001

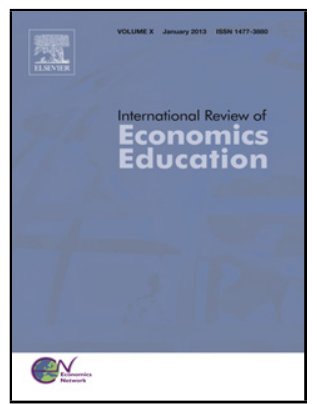
IREE 139

To appear in:

Received date: $\quad 23-4-2018$

Please cite this article as: Becker R, Birdi A, Flipping the Classroom: Old Ideas, New Technologies, International Review of Economics Education (2018), https://doi.org/10.1016/j.iree.2018.06.001

This is a PDF file of an unedited manuscript that has been accepted for publication. As a service to our customers we are providing this early version of the manuscript. The manuscript will undergo copyediting, typesetting, and review of the resulting proof before it is published in its final form. Please note that during the production process errors may be discovered which could affect the content, and all legal disclaimers that apply to the journal pertain. 


\section{Flipping the Classroom: Old Ideas, New Technologies}

Ralf Becker (University of Manchester) and Alvin Birdi (University of Bristol and The Economics Network)

\section{Introduction}

The technique of classroom flipping, by which the sequencing and nature of learning and teaching is configured in novel ways, has started to make an impact on the teaching of economics. To the extent that flipping involves a substitution of active learning methods for traditional lecture delivery, one might have expected a far earlier adoption of flipping techniques by economists. For some time, the pedagogical resources available to and being used by economists have included an array of active learning methods such as classroom games, experiments, polling software, data-based investigative work and the use of multimedia resources ${ }^{1}$. These are precisely the kind of methods that one can envisage supporting a flipped classroom pedagogy.

Indeed, the UK Economics Network has been advocating and training lecturers to use classroom games, polling software and multimedia in their teaching for well over a decade. Such active learning methods do not come without cost however. The real price of their adoption, and perhaps the reason for their lack of widespread use, is the freeing up of time within the traditional lecture or class. Flipping the classroom, in the sense of moving some material outside the classroom, provides an obvious complement to active learning techniques in that it is oriented towards making time available in formal teaching sessions for more active learning. If flipped learning has pedagogical benefits, economics as a discipline should be uniquely positioned to receive them.

This special issue of IREE collects some papers that aim to bring understanding to a method of learning and teaching whose methods and implementation, not to mention learning benefits, are not yet fully appreciated. Partly this lack of understanding arises from a sense that the teaching of economics has never been entirely didactic. It has always involved at least an element of flipping in that students have traditionally been asked to work before the tutorial, particularly on solving exercises and problems but also in reading, in order to actively discuss these problems in class.

Nonetheless, many instructors will be aware that the ideal of active discussion of exercises and papers in the traditional method has often faltered either because of lack of student preparation or because of a tendency of instructors to lapse into a mini-lecture format in their classes. Many instructors report exactly these problems in the training that the Economics Network delivers in the UK each year. Indeed, a portion of the Network's training each year is devoted to addressing the challenge that teaching sessions, particularly small group sessions, remain active and studentfocused.

\footnotetext{
${ }^{1}$ See for example the movie-based resources at http://dirkmateer.com/media-library.
} 
It might therefore be said that the idea of flipping discussed in these pages differs from the traditional method only in that it makes use of video technology and other multimedia assets to motivate out of class student engagement, but that in its nature and intent it is fundamentally the same. We do not disagree that certain elements of flipping have always been part of a properly configured pedagogy because the benefits of students engaging with material in active ways has been apparent for a very long time. However, though the elements of a flipped approach were always with us, at least in principle, the resources at our disposal to enable the success of the approach are richer and more readily available than at any previous time. As a result, there is the possibility that flipping may involve a more significant transformation of economics education than at any previous time.

We understand flipping in education to be a multi-faceted approach to the activation of student learning which involves an equally important consideration of what happens before and after the face-to-face class as within it. First, unlike many traditional courses in which lectures often cover material before students are asked to engage with it actively, there may be a re-sequencing of content so that students are set to work on material before it is treated in any depth by a lecturer. Second, the material made available to students is often in the format of videos or podcasts which, when complemented with traditional reading material, may enhance the motivation of students to engage with it. Third, this material may originally have featured as part of the content of a traditional lecture but which has been removed from the lecture to create time for other activities. Fourth, there is often deliberative activity within the classroom such as peer-to-peer instruction, the use of games, directed group study or team-based learning designed to be undertaken with varying degrees of instructor direction. Fifth, there may be specific material that is left for students to work on after the face-to-face session.

These elements in themselves contribute to increased student engagement with the material that is being taught. Evidence that just changing the classroom is not what is required can be found in Green (2014) which suggests that merely changing the classroom to activate learning may not be beneficial. Equally, just moving the content delivery from the lecture to online may also be ineffective or even detrimental (Green, 2014; Cosgrove and Olitsky, 2015).

In summary, the mature approach to flipping challenges the teacher to reconsider the complete design of a course rather than simply reorient its delivery. The fuller consideration involves the appropriate nature and location of learning activities within the parameters of both time and space. It may no longer be enough to think of what content belongs where and in what order. Rather, one will need to consider which student activities will be most conducive to learning and whether such activities are better placed before, during or after the face-to-face session, and moreover what kind of interaction with the material and with others is required. In this sense, flipping necessitates a fundamentally student-focused approach to engaging with content rather than an approach which is centred on the delivery of that content by staff in a methodical and long-established sequential manner. 


\section{What has changed?}

Lectures in which educators deliver content to students have been the mainstay of University education across centuries and continents. In some way this is astonishing as the effectiveness of lectures, even as a content delivery mechanism, has been questioned for some time. In a lecture on economics lectures John. B. Taylor (Stanford University) notes that such questioning dates back at least to the $18^{\text {th }}$ century writer Samuel Johnson.

At least two changes in recent years have laid the ground for the emergence of the flipped classroom. These are technical innovations and a better appreciation of how students learn. The idea that students learn best when they are using and activating their knowledge is now wellaccepted (see the meta-analysis by Freeman et al 2014). As noted above, there are various aspects of the economics discipline that have for some time lent themselves to active learning and in recent years these aspects have been further supported by technological developments.

Economics is increasingly reliant on game-theoretic thinking and this aspect of the discipline lends itself uniquely to classroom games or online experiments. The subject has always been empirically oriented ${ }^{2}$ and the increased availability of data and ease of access to suitable software has made the practice of statistical and econometric estimation and investigation within classes possible. The conceptual and technical nature of the subject lends itself to the kind of multiple choice questions that polling software (and indeed the kind of peer-instruction method discussed by Arico and Lancaster in this issue) was developed to support. The problem is not the lack of possibilities for active learning but freeing space to actually use them.

It may be the ability of individual lecturers to easily produce online videos to replace the lecture delivery of content that has facilitated the move to flipped learning more than any other change ${ }^{3}$. When material is delivered in this way students lose the ability to interrupt the lecturer to ask questions but gain the ability to easily speed up, slow down and repeat the delivery. It may even allow students to determine for themselves and personalised the order in which material is learned ${ }^{4}$.

Adding online videos to class contact and students' reading of written material has been a gamechanging innovation. While the benefits of this type of content delivery have been recognised for a long time (remember the attempts of various public broadcasters to beam white-coated scientists into our living rooms), the real step change for HEI has been the development of enabling technology (tablet input devices and screen recording software) that allow individual teaching staff to create such material relatively cheaply without requiring outside assistance.

\footnotetext{
${ }^{2}$ This empirical aspect of economics was somewhat perhaps surprisingly, neglected in the past in favour of a more theoretical approach. This is now changing and the CORE project (www.core-econ.org) has developed a significant re-sequencing of the taught economics principles course emphasising its empirical and hands-on aspects.

${ }^{3}$ In most cases these videos would be delivered to students using a virtual learning environment (VLE) which is another important enabling technology for flipping. However, VLEs have for long been used to support the delivery of traditionally structured courses and it is the combination of such technology with embedded video technology that makes a flipping approach easier to develop.

${ }^{4}$ Refer to Watson and Parker (2016) for an example where this may be a crucial element of a blended approach.
} 
This addition to our toolbox as lecturers has been crucial as we have seen it become increasingly difficult to engage students in large scale reading as a method to acquire content. Developments that contributed to this are a general decline in reading amongst young people (in general and as part of secondary education) combined with a growing reliance on information delivered through screen time (television and internet) and possibly a growing consumer attitude amongst students demanding more from universities than merely a reading list. While this development is much bemoaned amongst HEI teaching staff it is likely that it is irreversible and HEl education will have to be delivered within this new context. Producing online material that can easily be delivered outside the lectures, yet is obviously produced by university staff does allow teaching staff to create time in lectures for student-centred active learning where previously lecture time was seen as the main vehicle for content delivery.

\section{The Flipped Classroom and Student-Centricity}

Lecturers who want to implement a flipped classroom only do so when they have thought in a more holistic way about the way in which a course delivers learning opportunities to students. In some sense a move away from a lecture-centric approach to a blended delivery approach (potentially including flipped classrooms, but certainly including the online delivery of learning opportunities to students) is also a move from a teacher-centric teaching to a student-centred learning approach.

One of the time-honoured traditions of academia perhaps best illustrates the teacher-centric approach. If at any institutions a course is handed over from one lecturer to another this usually involves the handing over of lecture slides as the main document embodying the course content, the body of knowledge that lecturers attempt to impart to students. Other information, like tutorial questions and reading lists are understood in the context of the material that is delivered through the lecture and subordinated to it.

Students certainly understand this well - at many institutions, the assessed material is taken from the lecture content rather than the material that students might engage with outside the class. While it is unlikely that an individual University's rules contain such a stipulation both lecturers (in form of assessment setting) and students (in form of their revision work) tend to tacitly (or in some cases explicitly) reinforce such an understanding.

When a flipped classroom approach is used the central position of the lecturer and the lecture content comes under scrutiny as the prominent activity within a course. Demoting the lecture and the lecturer in this way has several effects and poses various challenges:

1. Students gain more control over the timing at which they study.

2. A successful implementation will have to change students' expectations about what is examinable and important within a course

3. A lecturer will have to carefully integrate all available material and point students towards a sensible study path. This will typically encourage lecturers to focus more on student's learning.

4. Alternative content delivery mechanisms have to be provided. Where they are different to merely pointing students to existing reading material this requires additional work (in the 
first instance). This provides challenges to departments in terms of rewarding staff for such development work. Where the non-lecture material is reading based lecturers will face the challenge of finding material which is well enough written such that they can expect students to engage with it.

5. Lecturers will have to rethink the activities that are undertaken in lectures, in most cases combining elements of active learning with some content delivery.

Much existing research published on flipped classrooms often focuses on this last aspect. Here, however, we do argue that the other aspects are equally as important to consider.

If, as some of the evidence in this issue suggests, there are pedagogical advantages to flipping the classroom, departments and staff will need to overcome some of the challenges noted in the list above, specifically the required change to students' expectations and the implied fixed costs of moving to a new delivery style.

We suggest that there may be an easy path from an existing, traditional, course unit to a unit that has flipped classroom components so that the move to the new way of teaching can be gradual and avoid an immediate and large fixed cost. Many institutions now routinely record lectures for use by students in revision. It may be argued that such lecture recordings reinforce a surface approach to learning because they provide resources that support the cramming of knowledge close to an examination. However, where such resources exist from previous years, extracts may be taken from them to quickly provide a set of video resources for a flipped course. There is nothing, after all, inherently good or bad in lecture recording technology: the same technology may be used to activate learning as to discourage it.

There is inevitably a more involved effort required to disrupt the tacit understanding that the examinable or important course material in some sense resides in the lecture content. One approach, used light-heartedly by a university vice president in India, is to state that "what I don't cover in lectures will be covered in the examination". But a more successful approach will be to ensure that students have a clear assurance of where the examinable material is situated. We have taken the approach of stating that certain chapters of a textbook contain the examinable material and that we will draw selectively on that material throughout all the components of the course, namely, videos, podcasts, class-session, online discussions, set readings and so on. What seems to be clear though is that an explicit articulation that the lectures do not solely contain the important course material is likely to be necessary in any serious reconfiguration of education along the flipped approach.

There is however more to the reconfiguration of expectations than simply the location of examinable material. Students will also have to accept that lecture and class attendance will be more useful if they have completed the required pre-lecture preparation and that lecturers will not necessarily cater for students that did not tackle the pre-lecture tasks. It may well be that in a transition to such a system, individual lecturers will have to accept that some students will dislike such a change, in particular, if it is not implemented across the breadth of units in an institution. Departments and Universities will have to find ways to look beyond the raw statistics of unit evaluations in order to evaluate the contributions of lecturers. 


\section{Getting to grip with the flip}

We have suggested flipping as an approach is more than simply active learning in the classroom but a comprehensive strategy around the design of learning. In line with time-honoured approaches to learning design it begins with learning outcomes and works through appropriate assessment methods with which to test the learning outcomes and only then to delivery and activities that will ensure students can prepare themselves appropriately. Nothing in the flipping approach questions this general design methodology. However, the final stage of deciding the learning activities has traditionally been somewhat limited. It has usually taken the form of deciding which content belongs in which lectures and how tutorials and classes will work in relation to these lectures.

None of this is surprising given that many universities organise their teaching around a set number of lectures and/or classes per course or module. Nevertheless, the challenge that the flipping approach poses is to think more broadly at this last stage of learning design. That is, to think through precisely how the time inside and outside classes is best used in conjunction with the multimedia resources that a lecturer can make available to students. One is therefore designing a set of student learning activities and processes rather than a content trajectory to be delivered by a lecturer. The pertinent considerations will involve what, precisely, will take place in the scheduled sessions and what are the dependencies in terms of student preparedness? What will be asked of students in advance of teaching sessions? What additional resources will be needed for students to successfully traverse this more independent and self-directed method of learning? How will students be supported and assured that they are doing what is required to be able to succeed in the assessments?

This special issue collects papers that are wide-ranging because this reflects the broad nature of questions and investigations that one can pursue in this area. Lombardini, Lukkala and Muukkonen (2018, this issue) compare different degrees of flipping in terms of their effects on attainment and student satisfaction. Their paper reminds us that flipping is a continuum that deploys more or less preparatory activity by students which is then used in more or less active ways in class. Given what we have said above about the challenge for student expectations, it may not be surprising that their findings suggest that different levels of flipping have very different effects. However, they find that a partial flip may be more successful to a fully flipped class. It may be that the sense of disorientation and cultural shift faced by students in a fully flipped scenario might explain this, or it may be, as the authors suggest, that a fully flipped class makes considerable demands on students in terms of workload.

The paper by Becker and Proud (2018, this issue) considers the use of flipping in a small class setting in econometrics courses. It is a reminder that the approach of flipping can enhance not just the more didactic form of delivery, namely the lecture, but also the economics tutorial which can often take the form of an unintentional secondary lecture. Though their data does not allow a causal identification of attainment in terms of teaching method, their study nevertheless points to the change in learning methods and involvement experienced by students in a flipped environment. 
Arico and Lancaster (2018, this issue) illustrate through two case studies, from economics and organic chemistry, how a flipped methodology can be complemented by other methods of active teaching such as peer instruction. Their case studies illustrate that flipping can encourage a new way of sequencing and ordering material that may have been taught in the same way for many years. They also note that the degree of success of a flipped course is dependent on the success with which engagement with preparatory material occurs. This signals the importance of expectations management in the success of flipping approaches. We have noted above that a clear articulation of the relationship between the various components of a course and the assessments is critical in ensuring student engagement with material that is now situated outside the traditional lecture. Arico and Lancaster also suggest that there is evidence that low performers may benefit more from a flipped course than traditionally successful students.

Another method of active engagement possible in a flipped environment is team-based learning (TBL) which is the basis of the paper by Odell (2018, this issue). This study of a macroeconomics class suggests that flipping associated with TBL has a positive effect on attainment and satisfaction. The study is interesting in that the pre-assigned material is of the traditional type, suggesting that flipping is not in itself dependent on video technology. However, the study does talk about a "readiness assurance" procedure which is what we feel is one of the key aspects of a successful flipped approach, namely, finding some way to plausibly indicate to students that the preparation for classes is the key to success. We have suggested that incentives for preparation can be created by use of videos and other resources as well as readings with which students are likely to engage. This paper suggests that flipping can be done without multimedia incentives. The key may be carefully articulating and signalling to students the material that will be used for assessment and examination purposes.

Calimeris (2018, this issue) looks at another dimension of flipping, namely the spacing effect. As we have noted above, the design of learning in a flipped environment requires careful attention to where, when and how learning activities take place. The spacing of activities is therefore a key variable in the design of flipped learning. Calimeris finds an effect of flipping on the attainment of students but no significant difference associated with the spacing effect. However, she finds that satisfaction and perceptions of active engagement in learning does increase with shorter and more regular contact with the instructor in flipped classes.

This brief selection of papers can only begin to touch the surface of the feature that contribute to a successful approach to flipping. They suggest that there is no fixed way to introduce flipping into an economics course. They also provide additional evidence that using the flipped classroom approach to increase the amount of active learning elements, has significant promise to deliver improved learning outcomes.

In our view the flipped classroom approach, as described above, has significant promise beyond the already existing implementations, mostly by enthusiastic teaching staff. Many of the technical challenges for this approach have now found cheap solutions that can be implemented by individual lecturers. It is likely that it is now the willingness, the availability of time, and the recognition and reward (or lack thereof) of any effort to change the delivery approach that will prove to be the most significant hurdles for further adoptions. 


\section{References}

Cosgrove, S.B. and Olitsky N.H. (2015). Knowledge retention, student learning, and blended course work: Evidence from principles of economics courses, Southern Economic Journal, 82, Issue 2, pages 556-579.

Green, A. (2014). The case for the traditional classroom, International Review of Economics Education, Volume 16, Part B, May 2014, Pages 87-99.

Scott Freeman, Sarah L. Eddy, Miles McDonough, Michelle K. Smith, Nnadozie Okoroafor, Hannah Jordt and Mary Pat Wenderoth (2014). Active learning increases student performance in science, engineering, and mathematics, PNAS, 23, 8410-8415.

Watson \& Parker, (2016) The hullaballoo over e-learning? Technology and pluralism in economics, Cogent Economics \& Finance 4: 1159813, http://dx.doi.org/10.1080/23322039.2016.1159813. 